\title{
THE BANFF INCORPORATION: \\ A LESSON IN COOPERATIVE FEDERALISM
}

\author{
FREDERICK A. LAUX*
}

The author outlines the process by which the Banff townsite was transformed from an entirely federal entity into a municipal corporation endowed with provincial powers. The article is written from a very unique perspective as the author was a participant in the process serving as a consultant to the Department of Justice during the negotiations. He begins by tracing the constitutional framework that originally created the town and considers how this framework administered the town up until its incorporation in 1989. He then examines the constitutional problems that had to be overcome to achieve this incorporation and describes the way in which they were resolved. Finally, he surveys the agreement and reflects upon the legal status of this new hybrid entity that the agreement created.
L'auteur décrit la démarche par laquelle la ville de Banff, entité jusqu'alors entièrement fédérale, a été transformée en municipalité dotée de pouvoirs provinciaux en 1989. L'article est écrit dans une perspective unique, vu que l'auteur a participé aux négociations à titre de conseiller auprès du ministère de la Justice. Il commence par retracer le cadre constitutionnel qui est à l'origine de la ville et relate comment l'administration s'était effectuée jusqu'alors. Il fait ensuite état des problèmes constitutionnels qu'il a fallu surmonter pour ériger cette ville en municipalité, et la façon dont ils ont été résolus. Finalement, il examine l'accord et la situation juridique de la nouvelle entité hybride qu'il a créée.

\section{TABLE OF CONTENTS}

I. INTRODUCTION .................... 634

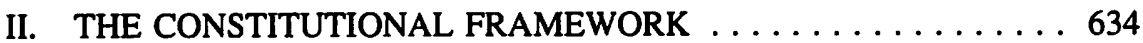

III. PRE-INCORPORATION TOWNSITE ADMINISTRATION $\ldots \ldots 636$

IV. MOVEMENT TOWARD LOCAL GOVERNMENT FOR

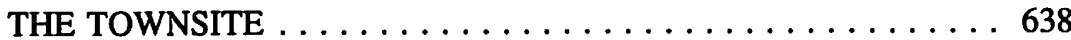

V. THE INCORPORATION PROCESS . . . . . . . . . . . 643

VI. THE CONTENT OF THE FEDERAL-PROVINCIAL

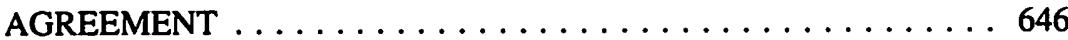

A. GENERAL MUNICIPAL FUNCTIONS OF

THE TOWN . . . . . . . . . . . . . . . . 647

B. LAND USE PLANNING FUNCTIONS OF

THE TOWN ..................... 650

C. PROPERTY TRANSFERS AND OTHER

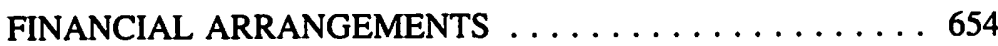

D. DISSOLUTION OF THE TOWN $\ldots \ldots \ldots \ldots \ldots \ldots \ldots 65$

E. MISCELLANEOUS PROVISIONS $\ldots \ldots \ldots \ldots \ldots \ldots 656$

VII. THE LEGAL STATUS OF THE TOWN $\ldots \ldots \ldots \ldots \ldots \ldots 668$

VIII. CONCLUSION $\ldots \ldots \ldots \ldots \ldots \ldots \ldots \ldots \ldots \ldots \ldots \ldots \ldots \ldots \ldots$ 


\section{INTRODUCTION}

The Governments of Canada and Alberta have not always been the best of friends. A decade ago the two were at serious odds about the marketing and export of Alberta produced fossil fuels. The Trudeau government's imposition of the National Energy Programme was and continues to be seen by Albertans as the crowning example of Central Canada's incessant exploitation of the West. More laterally, the two levels of government have failed to see eye to eye on such matters as the regulation of interest rates, federal transfer payments and, most topically, Senate appointment and reform. Despite these and other dramatic differences of opinion, the striking of the clock at midnight of December 31, 1989 heralded in not only the last decade of the Twentieth Century, but also signalled into being the first provincial local government unit within a hitherto federal enclave. At that time the Town of Banff was officially created as an Alberta municipal corporation and endowed with powers prescribed in Alberta statutes.

One who is familiar with the constitutional divisions of powers in Canada immediately sees the apparent contradiction. How can Alberta create a municipal corporation to exercise Alberta mandated local government functions in an area under federal jurisdiction by virtue of it being within a national park? Moreover, how can Alberta law exert control over lands owned by the Crown in right of Canada? The seeming paradox can be reconciled only by a full appreciation of the intricacies of the Constitution and of the creative spirit of cooperation between the Alberta and federal governments that allowed the Town to come into being in its present form, a result that is all the more noteworthy given the historic and current tensions between the two governments. This example of cooperative federalism resulted from two realities: it created a win-win situation for both governments and it was accomplished in the main outside the political arena and in a quiet, low-key fashion at the bureaucratic level. That aside, the purpose of this paper is to outline the constitutional problems that had to be overcome to create the Town and to endow it with its municipal powers, to explain how these problems were resolved, to describe what the end product looks like and, finally, to reflect upon the Town's legal status given its unique character.

\section{THE CONSTITUTIONAL FRAMEWORK}

As the reader will recall, through the combined effect of the Rupert's Land Act, ${ }^{1}$ the Manitoba Act, ${ }^{2}$ the Constitution Act, 1871 and a federal order-in-council, ${ }^{3}$ the Dominion government assumed all governmental authority over the western territory now comprised of Saskatchewan, Alberta, the Northwest Territories and the Yukon. Also, except for lands reserved unto the Hudson's Bay Company, the Crown in right of Canada became the owner of all lands in the territory. This resulted in the Dominion government also acquiring jurisdiction over the ceded lands under s. 91.1A (the public debt and property) of the Constitution Act, 1867 by virtue of its proprietary interest. 
Pursuant to the Dominion Lands $A c t,{ }^{4}$ in 1885 an area surrounding the mineral hot springs at Banff was reserved from "sale, settlement or squatting." The following year a decision was made by the Minister of the Interior to enlarge the reserve and to establish a park. To provide for the park, the Rocky Mountains Park Act ${ }^{5}$ was passed, which Act delegated management and control of the park to the Minister, subject to regulations made thereunder.

Upon creation of Alberta in 1905, the Alberta Legislative Assembly acquired lawmaking authority in the whole of the Province, much of which authority had the potential to apply to the Park. However, by s. 21 of the Alberta Act, ${ }^{6}$ ownership of the land in the Park (and, of course, other federal Crown lands, including all mines and minerals and all waters within the Province) continued to be vested in the federal Crown. Hence, the park remained under the control and administration of the federal government pursuant to s. 91.1A of the Constitution Act, 1867, and the Rocky Mountains Park Act continued in force. In 1911 the latter statute was replaced with the Dominion Forest Reserves and Parks $\mathrm{Act}^{7}$ under which, among other things, the Rocky Mountains Park (now Banff National Park) was continued as a "Dominion" park.

During the next twenty years uncertainties developed as to the extent to which Alberta laws operated in the Park. Also, Alberta, along with the other western provinces, lobbied Ottawa for the transfer to the provinces of the natural resources (lands and mines and minerals) that had been vested in the Dominion government since its take-over of Rupert's Land and the Northwestern Territory in 1870 . Such a transfer, the western provinces argued, would rightly put them into the same position as the original four provinces, which had acquired ownership of natural resources within their respective boundaries pursuant to s. 109 of the Constitution Act, 1867.

The problems concerning legislative jurisdiction within the national parks, and ownership of natural resources generally, were resolved when each of the western provinces entered into an agreement with the Dominion government pertaining to natural resources. Paragraph 1 of the Alberta Natural Resources Transfer Agreement conveyed most of the federally owned resources in Alberta to the provincial government, subject to Paragraph 14 thereof. By that provision all lands, together with all mines and minerals, in the then existing national parks within Alberta were reserved to the Dominion. Legislative jurisdiction within these parks was expressly assigned in Paragraph 15 of the Agreement to Parliament, except that the provincial laws could operate to the extent that they were not repugnant to federal laws:

15. The Parliament of Canada shall have exclusive legislative jurisdiction within the whole area included within the outer boundaries of each of the said parks notwithstanding that portions of such area may not form part of the park proper; the laws now in force within the said area shall continue in force only until changed by the Parliament of Canada or under its authority, provided, however, that all laws of the

S.C. 1872 , c. 23 , am. S.C. 1884 , c. 25.

S.C. 1887 , c. 32 .

1905, R.S.C. 1985, App. II, No. 20.

S.C. 1911 , c. 10. 
Province now or hereafter in force, which are not repugnant to any law or regulation made applicable within the said area by or under the authority of the Parliament of Canada, shall extend to and be enforceable within the same, and that all general taxing Acts passed by the Province shall apply within the same unless expressly excluded from application therein by or under the authority of the Parliament of Canada.

The Alberta Natural Resources Transfer Agreement was ratified by the Alberta legislature through the Alberta Natural Resources $A c t^{8}$ and by Parliament in a similarly named statute. ${ }^{9}$ Most significantly, the Agreement also was confirmed and incorporated as part of the Constitution of Canada by the Imperial Parliament through the Constitution Act, $1930 .^{10}$ Hence, the effect of Paragraph 15 was to confer a much broader legislative jurisdiction unto the Dominion Parliament than it could exercise under its power to legislate in respect of public property pursuant to s. 91.1A of the Constitution Act, 1867. That is, if it wished, Parliament could now assume all law-making authority in the Park, and provincial laws would not apply to the extent that Parliament had occupied a given field. Conversely, it would seem that, in the absence of federal laws on a particular subject, even provincial laws affecting federal property could operate notwithstanding s. 91.1A, given that s. 1 of the Constitution Act, 1930 stated that the provisions of the Agreement would have the force of law "notwithstanding anything in the British North America Act, 1867, or any Act amending the same or any Act of the Parliament of Canada."11

On the same date as the federal Alberta Natural Resources Act received royal assent, assent was given to the National Parks Act. ${ }^{12}$ The latter reflected the Dominion government's commitment to Canada's national parks by prescribing that any change in the boundaries of the existing parks could be made only by an Act of Parliament, that the parks were absolute game sanctuaries and that preservation and conservation were to be the guiding principles in park use and administration. Also, the Act changed the name of the Rocky Mountains Park to Banff National Park.

\section{PRE-INCORPORATION TOWNSITE ADMINISTRATION}

Governance and administration of Banff National Park evolved over the years to the point that, just prior to the Banff townsite incorporation, the regime which is now to be described was in place. Responsibility for overall administration, management and control was delegated to the federal Minister of the Environment by the National Parks Act. Day to day management throughout the Park was conducted by the Canadian Parks Service (a

S.A. 1930, c. 21.

9. Alberta Natural Resources Act, S.C. 1930, c. 3; am. S.C. 1931, c. 15 and S.C. 1945, c. 10.

10. 20-21, Geo. V., c. 26. For a detailed consideration of the Resources Transfer Agreements and regulation of natural resources generally, see G.V. La Forest, Natural Resources and Public Property Under the Canadian Constitution (Toronto: University of Toronto Press, 1969).

11. See Cherry v. Smith, [1933] I W.W.R. 205 (Sask. D.C.). For a more detailed discussion of the constitutional basis of parks administration, see N. Bankes, "Constitutional Problems Related to the Creation and Administration of Canada's National Parks" in J.O. Saunders, ed., Managing Natural Resources in a Federal State (Toronto: Carswell, 1986). 
branch of the Department of the Environment) under the supervision of the Park Superintendent. The Banff townsite itself was subject to the direct management of the Townsite Manager, a Parks Service employee, whose responsibilities included, inter alia, fire protection, domestic animal control, traffic control, some building inspections, some lease administration, business licences, development permits, public utilities and waste management. All of these tasks were performed pursuant to a host of National Parks Act regulations and Parks Service general policies. Electricity, gas, telephone and cable television service was supplied to residents of the townsite by Trans-Alta Utilities, Canadian Western Natural Gas, Alberta Government Telephones and a local cable television operator, respectively, pursuant to franchise agreements with the Federal government.

Ownership of all land in the townsite was in the Crown in right of Canada pursuant to an ongoing federal policy that any land needed for private development in the Park could only be leased from the Crown. ${ }^{13}$ While the terms and conditions of individual leases varied widely, in general, land leases in the townsite for residential purposes were for a period of forty-two years and leases for commercial purposes for a period of twenty-one years. Normally all fixed term leases were subject to renewal. Rental rates, which were paid to the general revenues of the federal treasury, were usually fixed for a ten year period and varied in amounts depending upon the size and use of the land being leased. A leased premises could be subdivided only with the consent and in accordance with the requirements of the Crown. Assignments of leases needed similar approval.

Leases were granted and assignments approved only for uses and developments required to serve park visitors and to meet the needs of the townsite residents. Significantly, as a matter of policy, permanent residency in the townsite was restricted by terms in residential leases to those persons who could establish a "need to reside". That is, only those persons (and their dependents) could take up residence who were engaged in providing essential services either to park visitors or to other permanent residents. Developments were regulated by the Parks Service pursuant to the Banff Townsite Zoning Regulations ${ }^{14}$ a set of rules similar in form and substance to those found in the typical land use and zoning by-laws extant in most urban Canadian municipalities.

However, not all governance of the townsite was exercised by the federal government. That is, pursuant to paragraph 15 of the Alberta Natural Resources Transfer Agreement, Alberta laws were applicable in those areas not federally regulated. In particular,

The policy of only leasing land in the National Parks is particularly important in connection with those parks which are not subject to the Natural Resources Transfer Agreements. In the nonagreement parks, the principal source of federal jurisdiction is s.91.1A of the Constitution Act, 1867. If the federal government were to convey a fee simple interest in land in such parks, that jurisdictional foothold would be gone for the land so transferred. (This is not to say that the peace, order and good government clause in the opening words of s. 91 would not be sufficient to clothe Parliament with at least some jurisdiction.) Of course, retaining power under s. 91.1 A is not a concern in the parks covered by the Resource Agreements because of the clauses in those Agreements conferring exclusive jurisdiction over the parks unto Parliament, which clauses became part of the Constitution by virtue of the Constitution Act, 1930. 
provincial statutes and regulations operated in the townsite in respect of police protection, education, hospitals and health services, social services, recreation, culture, certain inspection services and motor vehicle licensing. In the area of education, there existed the Banff School District No. 102, which was created under the auspices of the School $A c t^{15}$ and headed up by a school board elected under the Local Authorities Election Act. ${ }^{16}$ That board levied and collected taxes for school purposes, ${ }^{17}$ but it also levied taxes to obtain revenues for purposes of it providing such services as libraries, social services and recreational facilities. ${ }^{18}$ Moreover, the board was deemed by some provincial enactments to be an incorporated municipality for purposes of establishing its eligibility to receive certain provincial government grants and other transfer payments.

In addition to the school board, since $1921^{19}$ there has existed in Banff a locally elected citizen advisory group to which many matters of concern common to the residents and the Parks Service were referred for discussion and recommendation. The advisory group's status gradually evolved to the point where, in the mid-1980's, its existence was formalized in an agreement entered into between the federal Minister of the Environment and the local school board. That agreement named the advisory group the "Banff Municipal Committee" and prescribed that its membership was to consist of all the members of the school board (seven in number), together with up to six Parks Service employees, of which in practice only four were appointed. The agreement contemplated that the committee would meet regularly and would advise the Parks Service on all matters of local concern including, but not limited to, the issuing of business licences and development permits and the setting of water and sewer rates. Although the committee was strictly advisory in nature, it would appear that it played an influential role in the governance and administration of the townsite. ${ }^{20}$ Significantly, the agreement also stipulated that part of the committee's mandate was to promote local government in Banff townsite.

\section{MOVEMENT TOWARD LOCAL GOVERNMENT FOR THE TOWNSITE}

The permanent residents of Banff townsite had not been particularly happy with their status for a number of years. ${ }^{21}$ This was so notwithstanding they had a measure of control over some local affairs through their elected school board, and had considerable

R.S.A. 1980, c. S-3.1.

R.S.A. 1980, c. L-27.5.

Pursuant to ss. 163 to 166 of the School Act, R.S.A. 1980, c. S-3.1 the school board had the same power to impose and collect taxes as does the council of a municipal corporation under the Municipal Taxation Act, R.S.A. 1980, c. M-31 and the Tax Recovery Act, R.S.A. 1980 c. T-1. Under s. 3(2) of the Municipal Taxation Act the interest of a lessee of federal Crown property is subject to assessment for tax purposes as though the lessee was the owner of the property.

School Act, ibid. s. 165.

For a general discussion of the evolution of citizen participation in parks townsite administration, see W.F. Lothian, A History of Canada's National Parks Vol. II, at 43 (Parks Canada, 1977). At least this is the view expressed by James Barlow to the writer. Mr. Barlow, during the period prior to incorporation of the town, was the Parks Service appointee as Townsite Manager.

The comments that follow are based upon interviews the writer conducted with townsite residents who were active in local affairs diring the several years prior to incorporation. 
input into decision-making by the Parks Service through the elected advisory groups. Several reasons for the discontent are worthy of identification.

First, there was a common perception that decisions of the Parks Service in connection with such matters as the issuing of leases, the granting of business licenses and the approving of developments were often motivated by extraneous considerations rather than by a sound evaluation of what was in the best interests of the community. It was thought that all too often a decision made at the local level by the Parks Superintendent and his staff which did reflect local interests was overridden after the applicant sought and obtained the intervention of federally elected officials. In short, the perception was that influential persons were the beneficiaries of favourable treatment, while others were not.

A second concern was that, even where decisions were made by the Parks Service on sound basis, the process was altogether too protracted. Frequently a matter calling for a decision would shift back and forth between the Superintendent's office in Banff, the regional offices of the Parks Service in Calgary and its headquarters in Ottawa. Similarly, within Ottawa, a matter frequently moved from department to department, without timely resolution. When a decision was finally made, it was often seen to be by bureaucrats who had no sensitivity toward local conditions.

Perhaps the most significant complaints were those of a financial nature. Rental payments for many leases of commercial sites in Banff were, by the terms of the leases, calculated by federal authorities on the basis of the highest and best use of a site rather than having regard to actual use. For example, the lessee of a site devoted to a substantial shopping arcade containing a number of sub-tenants would pay no more rent than the lessee of a similar-sized site accommodating only one business and generating substantially lower revenues. Moreover, the common perception was that the federal treasury took considerably more out of the townsite in the way of rental revenues and utility charges than it put back in the way of municipal services. ${ }^{22}$ Indeed, residents were becoming increasingly alarmed with what they believed was a deteriorating municipal infrastructure (e.g. roads, utility lines and sewage treatment facilities) that Ottawa was not, in their view, attending to properly. Finally, residents paid provincial income and other taxes. However, since the townsite was not incorporated, the residents collectively were not the beneficiaries of all the types of gratis services and grants the provincial government was making available to incorporated Alberta municipal government units.

Although federal authorities did not necessarily agree with the townsite residents' view of things, they too were not entirely happy with the status quo. The Parks Service's principal mandate was and continues to be to administer all the national parks of Canada for the benefit of all Canadians. It was not well-suited to managing a townsite consisting,

The income generated within, and the operating expenses of, the townsite were paid into and out of the general revenues of the federal Treasury Department. In the process Ottawa appeared to be making a net profit out of the townsite operations of in excess of $\$ .5 \mathrm{M}$ per annum. That figure was ultimately used as the basis for fixing the annual rent the Town. after incorporation, was required to pay for land leased to it by the federal Crown for municipal purposes. 
most lately, of in excess of 5,000 permanent residents. Effective townsite management required the application of principles and practices (and, hence, a degree of expertise) that were not particularly relevant to national park administration as a whole. In addition, day to day confrontation with individual problems generated within the townsite tended to deflect departmental resources away from the Service's main mission. This was a problem not only at the local offices of the Service but also at its regional and Ottawa offices, given the propensity of residents and the townsite's citizens' advisory groups to take matters "upstairs".

The problems associated with the Parks Service's townsite administration motivated the federal government to launch several studies over the years. The first such study was prepared by the Institute of Local Government at Queen's University, Kingston. ${ }^{23}$ The authors of the study made certain recommendations as to how Alberta national parks townsite administration could be improved, but advised that no steps ought to be taken to establish local self-government as there did not appear to be any desire for such amongst the residents of the three townsites that were examined: Banff, Jasper and Waterton.

As a consequence of an apparent change in attitude among local residents about selfgovernment, in 1964 the federal government commissioned Thomas J. Plunkett and Associates to undertake a study of the feasibility of setting up some form of municipal government in Banff. The resulting report ${ }^{24}$ explored the possibility of the establishment of a municipal corporation under Alberta legislation, but rejected that option as inconsistent with the federal government's overall obligations in respect of Canada's national parks. Instead, it recommended that a municipal corporation be created to govern Banff townsite by the federal government under the auspices of the existing National Parks Act. Specifically, it was proposed that the governing body of the federally created municipal corporation would be a "board of commissioners" rather than an elected council. The board would consist of seven members, three of whom would be elected by the townsite residents in accordance with election procedures set out in the corporation's charter. The chairman and three commission members would be appointed by the Governor General in Council. Thus, control would remain in the federal government. Moreover, the report recommended that decisions made by the board of commissioners in certain key areas such as land development and capital financing be subject to the approval of the Director of the Park Services. In the end, the sole result of the Plunkett report was the appointment in 1966 of a Parks Service employee as townsite manager for Banff.

Dissatisfaction with the status quo remained. Consequently, continuing pressure was exerted on the federal and provincial governments by townsite residents to do something to correct perceived injustices. In January of 1970, plebiscites were held in both Banff

23. Report of the Institute of Local Government, Queen's University, Kingston, respecting certain aspects of the operation of Banff, Jasper and Waterton Lakes National Parks and the townsites therein. (National Parks Branch, 1960).

24. A Form of Municipal Govemment and Adminstration for Banff Townsite in Banff National Park (National Park Branch, 1965). 
and Jasper under the auspices of those communities' respective school boards. The results of the plebiscites indicated that the majority of persons who voted were in favour of forming municipalities under Alberta law. However, less than one-half of the eligible residents of each community actually participated in the vote.

As a consequence of continuing dialogue between the federal and Alberta governments, spurred by the discontent evident in Banff and Jasper townsites, the Alberta Department of Municipal Affairs conducted another study of the feasibility of local government for the two park communities. The "Banff-Jasper Autonomy Report" was tabled in the Alberta Legislature on April 7, 1972, and copies were forwarded to the federal minister in charge of national parks. The report essentially endorsed the proposition that the two townsite areas should be transferred to provincial jurisdiction and municipal corporations created. Nothing more than promises of wider consultation by the Parks Service with the locally elected advisory councils resulted from this study.

The next major initiative directed at local government for Banff townsite was in the form of yet another report prepared by the Alberta Department of Municipal Affairs in 1980 entitled "The Park Town of Banff: An Option for Local Government". 25 That report concluded that incorporation of Banff townsite as a town was financially feasible and recommended such an initiative. In particular, the report suggested the following:

- an agreement be entered into between the Alberta and federal governments to enable the incorporation of the townsite by the Province;

- generally, the corporation should have the same rights, duties and powers as pertain to other Alberta towns under existing provincial legislation;

- the boundaries of the town should be fixed by federal-provincial agreement, ratified by both Parliament and the Alberta Legislature; and special provisions should be made concerning all aspects of development of land within the town to ensure continuing federal government control by way of National Parks Act regulations, but recognizing that day to day administration of development matters should be in the town's hands.

Also, the report contained detailed proposals concerning the transfer to the new town of certain federal government assets needed for municipal purposes and the steps required to be taken by both levels of government to accomplish the objectives of the report. ${ }^{26}$

There followed an eight year hiatus during which there was much talk but little concrete action, save for the agreement referred to earlier that gave rise to the striking of the Banff Municipal Committee, whose mandate included promotion of municipal incorporation. A plebiscite asking the Jasper townsite residents whether they wished local government status was defeated in 1986. This motivated the promoters of Banff's Projects Branch and Glen Acom, Q.C., a private practitioner who was formerly Legislative Counsel in the Alberta Government. 
incorporation to do more research with the aim of selling the idea to the townsite residents. One of the principal results of the research was the publication in 1988 of a follow-up report to the study that had been prepared by the Department of Municipal Affairs in 1980.

The second report focused on the fiscal feasibility of incorporation, the object being to assure residents that local government would not result in higher costs. The data published in the study revealed a highly favourable ratio between residential and commercial properties in Banff as compared to other comparably-sized Alberta towns. Employing a ratio of 1:4 residential to commercial mill rate split - a scenario that likely would be followed by an average town with a property profile like that of Banff - the projection was that, in the event of incorporation, most property lessees in the townsite (both residential and non-residential) would experience significant reductions in total cost over that which would prevail if the townsite continued to be administered by the Parks Service. In projecting total cost to lessees in an incorporated townsite, the authors of the report assumed that each annual lease rental payment would be reduced to a nominal $\$ 1.00$ and be replaced by a fixed annual sum of $\$ 550,000$. to be paid to the federal government by the incorporated town out of its tax revenues. The $\$ 550,000$ figure was based upon the average annual net revenues (annual rental payments plus other operational revenues minus annual expenditures attributed to townsite operations) the federal Treasury realized in operating the townsite in the years 1983 to 1986 . It was assumed that $90 \%$ of the fixed annual payment would be made out of non-residential property taxes and the balance out of residential taxes. Also, based on undertakings from federal authorities, ${ }^{27}$ it was assumed that land, fixtures and equipment used in supplying municipal services to the townsite would be turned over to the municipal corporation at a nominal consideration.

Armed with what it perceived as proof that the financial position of the townsite's residents and business operators would be substantially enhanced by incorporation, the Banff Municipal Committee caused a plebiscite to be held in the townsite on June 13, 1988 asking the voters whether they were in favour of incorporation effective January 1, 1990. Based in large measure upon the financial arrangements contemplated in the 1980 report and the 1988 follow-up study, the majority of residents voting agreed that incorporation should be forthcoming.

Following the vote, an ad hoc tri-level steering committee was created, called the "Committee on Banff Incorporation" (COBI), comprising of representatives of the federal government (the Canada Parks Service and the Department of Justice), of the provincial government (the Departments of Municipal Affairs and Federal and Inter-governmental Affairs) and of the residents of the townsite (the school board members and some of the board's staff, together with a private municipal affairs consultant hired by the board). It fell to this task force to coordinate all of the things required to bring about the townsite's incorporation on the date projected in the plebiscite materials. 


\section{THE INCORPORATION PROCESS}

It is not unfair to observe that, as at the date of the plebiscite, the precise manner in which the incorporation was to be effected, and the powers that the corporation would exercise, were not by any means fully developed. There was an understanding that the federal and provincial governments would be involved in the incorporation and that a town was to be created which generally would have the same authority as any other Alberta town, but subject to a substantial continuing role on the part of the federal government in the regulation of land use in the town and in matters concerning the environment. However, the details were left to be worked out as the incorporation process evolved.

The first formal step leading to incorporation was taken by the federal government shortly after the plebiscite was held. In the early summer of 1988, Parliament passed an amendment to the National Parks Act ${ }^{28}$ by inserting the following:

9. The Governor in Council may, following the holding of a public hearing in the town of Banff in relation to the boundaries thereof, or in the town of Jasper in relation to the boundaries thereof, fix those boundaries by an order adding a description of them as a schedule to this Act, but a schedule so added is not subject to amendment by the Governor in Council.

9.1 The Governor in Council may authorize the Minister to enter into agreements with the government of Alberta for the establishment of local government bodies for the towns of Banff and Jasper and to entrust to those bodies such local government functions as are specified in those agreements.

This was the sole federal legislation under which the incorporation proceeded. Obviously, s. 8.1 reflects a policy decision that the powers of local governments for Banff and Jasper were to be to the liking of the federal government and were not to be left solely to the provincial law, as could have been the case having regard to s. 15 of the Alberta Natural Resources Transfer Agreement.

Since section 8.1 of the National Parks Act contemplated an agreement between the governments of Alberta and Canada, and as a consequence of a series of meetings between representatives of the two governments, Alberta for its part decided that it should have special legislation in place to accommodate the Banff incorporation. The result of that decision was the passage in the summer of 1989 of the Parks Towns Act. ${ }^{29}$

In sum, that Act conferred authority on the Province's Minister of Municipal Affairs to enter into an agreement with the Government of Canada for the incorporation of a town within any national park located in Alberta. It also authorized the Lieutenant Governor in Council to make an order incorporating a town where such was provided for in an agreement, such town to have the powers set forth in the agreement. Subject to the terms

28. S.C. 1988 , c. 48 (assented to August 18, 1988).

29. S.A. 1989, c. P-1.5. Although the Act was passed in early August of 1989, working drafts were in existence much earlier in the year. The content of the Act was not fixed until after it became apparent what would be included in the federal-provincial agreement. 
of the agreement, any town so formed was to be regarded as a town for all purposes as though it had been formed under the Municipal Government Act. ${ }^{30}$ The Minister was also empowered to make regulations providing for the exercise of transitional powers by a school board operating in a national park, for the transfer from such a school board to a newly incorporated town of any municipal functions or services previously exercised or provided by the board and, subject to the terms of any agreement, for the dissolution of such an incorporated town. To ensure that the administrative steps taken by the school board preparatory to incorporation would be unimpeachable, the Minister's regulation granting official transitional powers to the board could, by the terms of the Act, be made retroactive to the date the Banff incorporation plebiscite was held. On August 24, 1989, the Minister made such an order in respect of the Banff School Board. ${ }^{31}$ Lastly, the Parks Towns Act provided that Banff's mayor and council were to be elected on October 16,1989 , the date fixed for general municipal elections throughout the Province, and that the provisions of the Local Authorities Election $A^{32}{ }^{32}$ were to apply to the election.

It should be stressed that the content of the Parks Towns Act was the product of negotiations between the two levels of government, and embodied the principle that an incorporated park town would essentially be a creature of the Province and not of the federal government. The objective was to place the town's residents into a position relative to local government similar to that of the residents of other Alberta incorporated municipalities.

The task of drafting the federal-provincial agreement contemplated by s. 8.1 of the National Parks Act and the emerging provincial Parks Towns Act fell to federal lawyers. ${ }^{33}$ Preliminary drafts of the proposed agreement were prepared in late 1988, but it was not until the early summer of 1989 that polished versions emerged. After thorough review at meetings between the federal lawyers and key Parks Service personnel, two alternative draft agreements were presented to the Alberta Department of Municipal Affairs for review and comment. ${ }^{34}$ One draft contemplated that all municipal functions, save those concerning land use planning and regulation, would be entrusted to the town through the agreement. Consistent with the understandings arrived at prior to the plebiscite, planning functions were to be exercised by the town if and to the extent authorized by regulations made under the National Parks Act. In other words, that aspect of local government was to remain within the exclusive control of the federal government.

The alternative draft would have made the planning functions an integral part of the agreement and, therefore, subject to some provincial control. In the end, this alternative

30.

R.S.A. 1980, c. M-26. This is the legislation under which all Alberta municipal corporations, save counties, derive their existence.

Alta. Reg. 381/88.

R.S.A. 1980 , c. L-27.5.

Included in the group were several federal Department of Justice lawyers assigned permanently to the Department of the Environment and who were headquartered in Ontawa, a lawyer in the Edmonton regional office of the Department of Justice and the writer, who was retained by the Department of Justice as a consultant.

34.

The key person involved from this Department was one of the deputy ministers, Toin Forgrave. 
was agreed upon between the representatives of Canada and Alberta, and a draft agreement to that effect was presented to COBI for its consideration. On July 13, 1989 a day-long meeting was held by $\mathrm{COBI}$ in Banff, at which the writer gave a line-by-line briefing on the content of the draft agreement for the benefit of the COBI's townsite representatives, none of whom had previously been privy to its contents.

On the whole, the draft agreement was favourably received by the townsite representatives, although there were a few areas of major concern. ${ }^{35}$ In particular, there was objection to the following:

- a clause in the draft agreement stating the townsite's objectives, which were perceived as too restrictive of the town's powers; ${ }^{36}$

- clauses that required the approval of the federal Minister of the Environment before certain by-laws, resolutions and actions of the town would become operative;

- clauses empowering the federal government to collapse the incorporation under certain circumstances; ${ }^{37}$

- inclusion of an escalation formula that would have resulted in periodic upward adjustments of the annual $\$ 550,000$. payment to be made by the Town to the federal treasury.

There were also a number of comments directed less at substance and more to the form of drafting of some other clauses of the proposed agreement.

As a consequence of the shortcomings perceived by the local representatives (concurred in by provincial representatives), several weeks of negotiations ensued between the two levels of government, with the provincial negotiators acting in large part as spokespersons for the townsite residents. Almost all the housekeeping changes that were requested were made, and the federal government gave in to demands that the annual $\$ 550,000$ payment be a fixed sum and not be subject to escalation. ${ }^{38}$ However, Canada maintained its position that the agreement must contain a purpose clause that clearly identified the townsite's unique status as a functional part of a national park. Also, the federal government prevailed in large measure on the points concerning its continuing supervisory role, although some rewording of the agreement was adopted to emphasize that its concern was principally in the areas of protecting the park environment and land use regulation. In the weeks before the signing of the agreement a few additional changes were made at the behest of the federal Treasury Board, such changes being aimed at minimizing certain potential ongoing federal liabilities, particularly those that might arise out of existing townsite utility franchises. General of the Parks Service.

For a discussion of the objects clause see note $\mathbf{4 8}$ and accompanying text, infra.

37. See discussion in notes 46,67 and 70 and accompanying text, infra.

38. The main point made by the school boand on behalf of townsite residents was that the federal government had earlier committed itself to a fixed sum and the plebiscite had proceeded on that basis. 
On December 8, 1989, Her Excellency, the Governor General, issued a formal Order authorizing the federal Minister of the Environment to execute the draft agreement, which was attached as a schedule to the Order. ${ }^{39}$ On December 12, the agreement was signed by the federal Minister of the Environment, Lucien Bouchard; by the provincial Minister of Municipal Affairs, Raymond Speaker; and by Alberta's Minister of Inter-governmental Affairs, James Horseman. ${ }^{40}$ On the same date, the Minister of the Environment issued a document entitled "Instrument of Entrustment of Local Government Functions to the Town of Banff" ordering and declaring that:

1. Effective January 1, 1990, the Corporation of the Town of Banff, and its council, officers, employees, boards, committees and other agencies, is hereby entrusted to exercise all those local government functions pertaining to the Town set out and described in the Agreement attached hereto as Schedule "A".

2. The local government functions herein entrusted shall be exercised in accordance with the terms, conditions, limitations, restraints and provisos set out in the aforesaid Agreement.

Finally, on November 14 the Lieutenant Governor of Alberta issued an Order ${ }^{41}$ pursuant to the Parks Towns Act as follows:

\footnotetext{
"Upon the recommendation of the Honourable the Minister of Municipal Affairs, the Lieutenant Governor in Council, pursuant to section 3 of the Parks Towns Act, forms the area described in Schedule "A" and illustrated in Schedule "B" into The Town of Banff, effective January 1, 1990."
}

As of January 1, 1990, the corporation of the Town of Banff came into being, but due to s. 15 of the Alberta Natural Resources Transfer Agreement and the fact that on that date there still remained in force a number of federal regulations that had been made pursuant to the National Parks Act, the Town did not acquire the full authority authorized by the incorporating instruments. This occurred, however, on April 19, 1990, the date upon which all National Park Act regulations pertaining to subject matters assigned to the Town by the agreement were either repealed in whole or rendered inoperative within the Town's boundaries. ${ }^{42}$ By that date, the Town council had passed by-laws in respect of those subject matters and thus, pursuant to the terms of the agreement to that effect, the by-laws automatically went into force. From that point, the Town assumed all the functions conferred upon it in the incorporating instruments.

\section{THE CONTENT OF THE FEDERAL-PROVINCIAL AGREEMENT}

The federal-provincial agreement, titled the "Town of Banff Incorporation Agreement," consists of a short preamble and thirteen articles, along with three schedules. In all, the agreement takes up forty-six double-spaced typewritten pages. The first article defines words and terms used throughout the agreement. By Article 2 the parties agreed that

41. O.C. $726 / 89$.

42. P.C. 1990 - 728. 
there would be established a municipal corporation to be known as the "Town of Banff," such corporation to be created pursuant to the Parks Towns Act. Each party also agreed to do all things necessary to enable the incorporation to occur effective January 1, 1990. Article 3 fixes the Town's boundaries (subject to a federal order-in-council pursuant to s. 8 of the National Parks Act) by reference to a plan filed on November 29, 1989 in the Canada Land Surveys Records at Ottawa, and provides that such boundary may be changed only by an amendment to the National Parks Act. This essentially leaves the matter of boundary alteration within the exclusive jurisdiction of Parliament. Article 4 is concerned with the general municipal functions of the Town and Article 5 with its planning functions. A detailed description of the more salient parts of Articles 4 and 5 is warranted.

\section{A. GENERAL MUNICIPAL FUNCTIONS OF THE TOWN}

In approaching the task of drafting the parts of the agreement concerning the Town's jurisdiction, the draftspersons had regard to the following principles:

- exclusive jurisdiction over and responsibility for national parks rests with the Parliament of Canada under the Constitution, and provincial laws may apply only to the extent permitted by Parliament;

- Parliament's constitutional mandate reflects the principle that national parks and their component parts are a national resource that exist for the benefit of all Canadians and as such there should always be a national voice and perspective in the running of the affairs of incorporated park towns;

- because of the Constitution and the nature of national parks, Canadians will continue to hold the federal government accountable for that which occurs in the parks; hence the national government should neither abdicate nor be seen as abdicating its responsibilities for the affairs of park towns;

- many of the political, social and economic problems confronted in larger urban park communities, like Banff, are of local interest only and can best be addressed at the local level;

- local policy and decision-making that directly affects matters of national concern most notably land use and the park environment - should be subject to national accountability through some process that requires federal approval;

- for both political and pragmatic reasons, policy matters of purely local concern, and day-to-day administration, ought to be carried out with a minimum of federal government involvement;

- in clothing the residents of Banff with local self-government, the model of Alberta towns should generally be followed, and that model ought only be digressed from to the extent necessary to reflect the unique nature of Banff as a national resource and the fact that the sole landowner is and will continue to be the Crown in right of Canada;

- the incorporation should reflect the various understandings and informal undertakings arrived at between the two levels of government and the townsite residents leading up to the plebiscite of June, 1988.

During the early stages of drafting, rather than creating a detailed set of tailor-made rules applicable only to Banff, the decision was made to utilize existing Alberta laws 
pertaining to towns, subject to such modifications as were deemed essential to reflect the above principles. Consequently, a review of in excess of one hundred Alberta statutes, and regulations made thereunder, was undertaken by federal lawyers to determine the extent to which existing Alberta laws were appropriate to the soon to be incorporated Town. In the result, and subject to other clauses in the agreement, ${ }^{43}$ Article 4 provides that effective January 1, 1990 the Town (which is defined to include the council, officers, employees, boards, committees and other agencies of the Town) is to have:

4.1 ... all the rights, obligations, duties, powers and functions, and be subject to the same limitations and restraints, provided for by the laws of Alberta as they existed on January 1, 1989, that apply to towns incorporated pursuant to the Municipal Government Act.

January 1, 1989 was chosen as the reception date for Alberta's laws for the simple reason that the review of the statutes and regulations preparatory to the drafting of the agreement occurred in early 1989 . The date selected thus obviated the need to review changes in the Alberta laws that occurred between that date and the date of signing of the agreement. However, by Article 4.2, the parties agreed that the federal minister may declare applicable to the Town in whole or in part any changes to Alberta laws pertaining to towns made after January 1,1989 . This process avoids the need to await amendments to the agreement before desirable changes in Alberta laws pertaining to towns become operative in Banff. A companion clause requires the formation of a liaison committee, consisting of representatives from the federal government and the Town (and of the provincial government, if it so wishes), which is to meet on a regular basis for the "exchange of views and the discussion of matters of mutual interest". It is anticipated this forum will be used to ensure that developments in Alberta law will be reflected in the Town's mandate.

Only a few sections of the Municipal Government Act were excluded from applying to Banff, ${ }^{44}$ and several modifications were made to other applicable statutes. ${ }^{45}$ However, by-laws and resolutions of the Town (and amendments thereto) affecting the flora, fauna or water bodies within the townsite and those concerning waste disposal, cemeteries and signs become operative only upon the approval of the federal minister in charge of administration of the National Parks Act, or his delegate. ${ }^{46}$ This requirement reflects the principle that the integrity of the park environment, including that falling within the Town's boundaries, remains a national concern.

43. The agreement states that it is paramount to any conflicting Alberta law that applies to Banff.

44. Sections 12 - 25 (amalgamation, annexation and dissolution); s. 155 (use of weather modification devices); s. 160(1)(f)(ii) (control of diseases in animals and plants); s. 195 (construction of texas gates); s. 261(1) (maintenance of zoos); and s. 219 (operation of airports).

For example, s. 52 of the Law of Property Act, R.S.A. 1980, c. L-8 and the Tax Recovery Act, R.S.A. 1980, c. T-1.

46. The agreement delegates considerable authority to the federal minister in charge of administering the National Parks Act, currently the Minister of the Environment. To ensure expeditious decisionmaking at the federal level, the agreement contemplates that there will be delegation by the Minister of many of his powers to Parks Service personnel located at Banff, most likely the Park Superintendent. 
The jurisdiction conferred on the Town is further modified by Article 4.3, which sets forth the purposes and objectives of the townsite ${ }^{47}$ as follows:

(a) to maintain the townsite as part of a World Heritage Site;

(b) to serve, as its primary function, as a centre for visitors to the Park and to provide such visitors with accommodation and other goods and services;

(c) to provide the widest possible range of interpretive and orientation services to Park visitors;

(d) to maintain a community character which is consistent with and reflects the surrounding environment; and

(e) to provide a comfortable living community for those persons who need to reside in the townsite in order to achieve its primary function. ${ }^{48}$

This clause met with some resistance at the local level on account of it being perceived as too narrow and as inviting judicial challenges to Town actions. Nonetheless, its inclusion was insisted upon by federal authorities to serve as a reminder to the Town's officials that many of the activities that might be appropriate to an ordinary Alberta town are not necessarily appropriate to Banff. ${ }^{49}$ By another clause in Article 4, the Town is prohibited from granting a business licence to an enterprise that cannot reasonably be regarded as necessary to meet the purposes and objectives set out in Article 4.3.

Article 4 contains additional clauses aimed primarily at clarifying the Town's powers having regard to the fact that virtually all land within the Town boundaries are and will continue to be owned by the Crown in right of $\mathrm{Canada}^{50}$ and that private land holdings are restricted to leasehold or other lesser interests. Specifically, the Town is empowered to acquire ${ }^{51}$ only a leasehold or lesser interest in land (and it may dispose of any interest it has acquired), and such acquisition is subject to the approval of the federal minister. Similarly, dominion and control over water bodies, or the bed and shore thereof, is to remain in the federal government unless otherwise subsequently agreed. Several clauses were inserted into Article 4 to ensure that no doubt exists as to the Town's authority to tax private leasehold interests and to recover tax arrears by means of tax liens against delinquent taxpayer's property interests.

47.

48.

49.

so.

51.

This clause is taken from the Banff National Park Management Plan which had earlier been adopted under the National Parks Act to regulate development in the whole of the park.

Note, the clause addresses the role of the townsite and not of the corporate entity. In other words, it is aimed more at things physical rather than political and social.

The objects clause is also reproduced in the Banff Land Use By-law, although with some modification in wording to accommodate local concerns. Ironically, although the council-elect objected to its inclusion in the Land Use By-law, the council used it in January of 1990 as the basis for rejecting an application for a development permit by the Ripley's Believe it or Not people who wished to set up a tourist attraction in Banff.

The only exception is land held by the Canadian Pacific Railway for railway purposes.

The power to acquire land by agreement or by expropriation (and to dispose of land) conferred on municipalities by the Municipal Government Act applies to the Town. 
In the end, almost all Alberta laws of general application empowering towns to exercise jurisdiction and requiring them to assume responsibilities apply in Banff. It is to be noted that many of such laws also confer jurisdiction on provincial government agencies to exercise powers that may directly affect Banff. For example, the Municipal Government Act grants jurisdiction to the provincially appointed Local Authorities Board to make rulings on such matters as money by-laws and requests from municipalities to acquire land outside their boundaries. Similarly, the consents of the Alberta Minister of Municipal Affairs and other cabinet ministers ${ }^{52}$ must first be obtained by a municipality before it may exercise certain powers. These provincial entities thus will have jurisdiction in Banff. The same is true of other provincial agencies exercising powers under other enactments. Examples include the Land Compensation Board, which fixes compensation in disputed expropriation proceedings pursuant to the Expropriation Act ${ }^{53}$ the Alberta Assessment Appeal Board, which hears property tax appeals pursuant to the Municipal Taxation Act ${ }^{54}$ and the Alberta Building Standards Council, which hears appeals from compliance orders issued by building inspectors pursuant to the Uniform Building Standards Act. $^{55}$

\section{B. LAND USE PLANNING FUNCTIONS OF THE TOWN}

Throughout the discussions leading to the Town's incorporation, there was general understanding among those concerned that the federal government would continue to play an active role in the regulation of land use within the Town. The reason for this being that, first, all land within the Town was owned by the Crown in right of Canada and, second, land uses within the Town would have a direct impact on the park environment (both aesthetically and physically) and on visitor experience generally.

Prior to the incorporation, the subdivision of land within the townsite was under the control of the federal Crown by virtue of its rights incidental to ownership of the land. Every lease issued by the Crown for an area of land contained a term requiring the consent and approval of the Crown to any sub-lease of either the whole or any part of the demised premises. Leases were administered in Banff townsite pursuant to the National Parks Lease and Licence of Occupation Regulations. ${ }^{56}$ These Regulations were principally concerned with such matters as who was eligible to lease land, the duration of the lease and the rental rate. Subdivision was strictly a matter of contract between the Crown and a lessee, and the latter was not protected by the sophisticated rules, procedures and rights of appeal that generally prevail throughout Canada in the case of a proposed subdivision of privately owned lands.

The consent of the provincial Minister of Transportation is required for certain road closures. Since roads in Banff will be on land owned by the federal Crown, the agreement specifically states that the federal minister shall exercise the power conferred in the Municipal Government Act on the Minister of Transportation in connection with roadways in Banff. Otherwise, the powers conferred on provincial ministers by the Municipal Government Act and other applicable legislation will be exercised in Banff by those ministers.

R.S.A. 1980 , c. E-16.

R.S.A. 1980 , c. M-31.

R.S.A. 1980 , c. U-4.

SOR/81-627. 
Developments were controlled through a permit system administered under the auspices of the Park Superintendent pursuant to the Banff Townsite Zoning Regulations. ${ }^{57}$ Those Regulations were similar in form and substance to the typical land use or zoning by-laws found in most Canadian municipalities. The townsite was divided into a number of land use districts, and the uses authorized for each district were listed. In addition, the development standards for such things as yard space, building height and form, parking space and yard storage were set out in detail. Subject to a limited variance power exercisable by the decision-maker on development permit applications upon the nonbinding recommendation of a "committee of adjustments", no development could be undertaken within the townsite that failed to comply with the Regulations.

As mentioned above, initially, consideration was given to structuring a land use planning regime for Banff outside of the incorporation agreement and through federal regulations made under the National Parks Act. Employing such a model, the difference between the new regime and the old would have been that the new federal regulations would have referentially incorporated certain parts of Alberta's Planning Act and would have delegated many of the planning functions to the Town and its agencies. However, after further review and discussion with provincial representatives, the decision was made to utilize the agreement in much the same way as was done in respect of the general local government functions. Accordingly, Article 5 of the agreement lists certain sections of the Planning Act that were in effect in Alberta as of January 1, 1989 as operative in the Town, and grants power to the federal minister to declare operative in the Town whichever changes to the Act made after that date which he considers appropriate.

The majority of the planning powers and duties conferred on other Alberta municipalities pertain to Banff, and these are to be exercised in accordance with the procedures prescribed by the Planning Act. However, because of Banff's unique circumstances (particularly in relation to land ownership), certain key provisions of the Planning Act do not apply in Banff, and others that do apply have been modified. Some of the more important differences between ordinary Alberta towns and Banff that emerge are worthy of mention.

First, all the provisions of the Alberta Planning Act dealing with regional planning and regional planning commissions have been excluded. In their place, the agreement contemplates that regional planning will be done under the auspices of the federal minister through an instrument that existed at the time of the agreement: the "Banff National Park Management Plan". That plan is given a status by the agreement similar to that given to a regional plan by the Planning Act. ${ }^{58}$ Second, all sections of the Planning Act conferring jurisdiction on the Alberta Planning Board ${ }^{59}$ and on the Lieutenant Governor

\footnotetext{
57. C.R.C. c. 1110.

58. All municipal plans and by-laws, and all development and subdivision approvals, must conform to the Management Plan just as the Planning Act requires their conformity with any adopted regional plan.

The Alberta Planning Board's main functions are to approve regional plans, to hear disputes arising out of the operation of regional plans, to settle inter-municipal planning disputes and to hear subdivision appeals.
} 
in Council ${ }^{60}$ do not apply in Banff. Similarly, wherever the Planning Act confers power on the Alberta Minister of Municipal Affairs in sections that apply to Banff, the agreement provides that such power is to be exercised by the federal minister. Hence, unlike the case of the general municipal functions described earlier, no provincial agency has planning jurisdiction in the Town. ${ }^{61}$

As is the case in other Alberta municipalities, the principal agencies that will exercise planning functions in the Town (aside from the federal minister) are the council, a development officer, a municipal planning commission and a development appeal board; the latter three being appointed by the Town council. The municipal planning commission is empowered to decide those development permit applications not assigned to the development officer and is also the decision-maker of first instance for all subdivision applications. ${ }^{62}$ The development appeal board will hear development permit and subdivision appeals. ${ }^{63}$ Both bodies must, by express clauses in the agreement to that effect, have one member who is a nominee of the federal minister, the object being to inject a federal perspective in day to day planning administration. In exercising its appellate jurisdiction, the development appeal board will have a more restricted variance power than is conferred by the Planning Act on other Alberta development appeal boards.

The principal planning instruments that will regulate subdivisions and developments in the Town will be the general municipal plan and the land use by-law, both of which are to be adopted by the council. However, unlike the case of general municipal plans and land use by-laws elsewhere in the Province, those instruments (and any amendments to them) become operative only upon the approval of the federal minister. Obviously, this proviso injects a substantial degree of federal control over land use in Banff.

Since the protection and enhancement of the environment of Banff National Park is a major federal responsibility, the agreement requires that every subdivision and development proposal within the Town boundaries is subject to the federal Environmental Assessment and Review Process Guidelines Order $^{64}$ (EARP), which Order has been passed under the Department of the Environment Act. ${ }^{65}$ The Order itself provides that every development proposal to which it applies must undergo an environmental impact screening by a federal agency to ensure that the project, either during or after its construction, will not have an unacceptable negative environmental impact. Depending on the nature of the proposed development, and the perceived gravity of its impact, the EARP process can range anywhere from a pre-approval by the screening agency to an elaborate public hearing. Where potential environmental harm is detected during the

The Lieutenant Governor in Council is empowered by the Act to make regulations pertaining to such matters as subdivisions, special planning areas and land surrounding airports.

In all, close to one-half of the provisions of the Planning Act will not apply in Banff.

The agreement incorporates most of the substantive and procedural subdivision rules set out in the Planning Act, thus making fundamental changes to that which prevailed in Banff prior to incorporation.

Elsewhere in Alberta, subdivision appeals are heard by the Alber:a Planning Board.

SOR $84 / 467$.

R.S.C. 1985 , c. E-10, s.6. 
review, the reviewing body may prescribe that mitigative measures be taken to minimize potential harm.

By the terms of the agreement, the screening authority for projects in Banff will be the federal Department of the Environment. Many development projects in the Town will be of a routine and repetitive nature and thus are capable of assessment before the fact. Consequently, as a matter of practice, it is anticipated that the Department will issue policy directives to the Town's administrators that will identify which kinds of subdivision and development projects are pre-approved, and will prescribe what mitigative measures, if any, must be employed. Such a pre-approval procedure should reduce delays that otherwise might be caused by the EARP process. Projects that are not pre-approved will have to be submitted to the Department by the developer or by the Town's administrators prior to any planning approval being granted. The Department will review each project on its merits and, if warranted, a full-scale environmental impact review (including hearings) will be conducted.

Upon a project have cleared the EARP process, a formal planning decision will be rendered. If the project is approved, any mitigative measure required under EARP (by terms in the agreement to that effect) will become conditions of the development permit or subdivision approval, as the case may be. Such conditions are then enforceable in the same manner as are any other conditions that are attached to an approval pursuant to the operative planning legislation.

While the Town will be exercising many planning functions in much the same way as other Alberta towns, ${ }^{66}$ there will be substantial federal control because of the requirements outlined above. However, federal control does not stop there. By Article 6.3 of the agreement, if the federal minister is of the opinion that any planning by-law, resolution or other action (which includes issuance of a development permit or granting of a subdivision approval) taken by the council or other town agency is inconsistent with the objectives of the townsite as set out in Article $4.3{ }^{67}$ or is in derogation of the environmental integrity of the park, the federal government (through the federal minister or the Governor General in Council) may do one or all of the following:

- declare such by-law, resolution or action to be inoperative in whole or in part;

- withdraw any or all of the planning functions entrusted by the agreement to the Town and its agencies; and

- make regulations or take such other action as it considers appropriate, which regulations or actions will be paramount to anything done by the Town or its agencies.

In short, Article 6.3 provides a form of "fail-safe" mechanism against any perceived irresponsible Town action. The ultimate control is that the federal government unilaterally may collapse the whole of the planning regime set up for the Town by the agreement and in Banff" (1990), Alberta and Northwest Territories Joumal of Planning Practice. 
reassert planning jurisdiction in its entirety over the townsite. This extraordinary federal power, however, does not apply to the other municipal functions of the Town.

\section{PROPERTY TRANSFERS AND OTHER FINANCIAL ARRANGEMENTS}

Consistent with the general understandings existing at the time of the 1988 plebiscite, the agreement obligates the Government of Canada (hereinafter called "Canada") to lease, licence or confer easements to the Town in respect of all land used by the Parks Service for municipal operations and services as at the date of the execution of the agreement. The precise lands are identified in Schedule "A" and include, inter alia, all public streets, lanes and walkways; the townsite's firehall and sewage treatment sites; the cemetery; the Parks Service work station; public parking lots; parks; and lands to be used for institutional and industrial purposes by the Town. In return, the Town is required to pay a fixed annual rent of $\$ 550,000$. to Canada, which sum is deemed to be an ordinary municipal expense for purposes of fixing property tax mill rates. Canada also agreed to transfer to the Town for $\$ 1.00$ ownership of the inventory of fixtures, structures and equipment set out in Schedule "B", which on the date of signing of the agreement were being used by the Parks Service to provide municipal services. Listed in the Schedule are such items as motor vehicles, road maintenance equipment, tools, traffic control equipment, water and sewer mains and other associated works, certain office furnishings, waste disposal equipment and park furnishings. All of the rights and obligations of Canada arising out of existing utility franchise agreements with utility companies are to be assumed by the Town upon the consent of the franchisees. The Town is required to indemnify Canada for any claims made by franchisees arising out of events occurring after the date of incorporation.

The Town boundaries encompass areas of raw land to accommodate future developments, which areas were not at the time of execution of the agreement under lease. To enable Canada to avoid the responsibility of maintaining those lands, the parties agreed that the land (identified in Schedule "C") would be licensed to the Town for a consideration of $\$ 1.00$. It was also agreed that when the licensed lands, or any parts thereof, ripen for development, Canada will grant leases to the developers after all necessary subdivision and development approvals have been obtained. The consideration for a given lease is to be fixed by the federal minister after consultation with the Town and the developer, the intent being that the price be the fair market value of the leasehold interest being conveyed. If any of the undeveloped land is required by the Town for municipal purposes, the same process will be followed.

As mentioned previously, prior to incorporation the cost of municipal servicing was absorbed by the federal government. It in turn derived revenues from, among other things, annual lease rental payments. In return for the Town assuming the cost of all municipal services, under Article 11 of the agreement, Canada undertook to amend all existing leases to reflect an annual rental of $\$ 1.00$. All new leases granted by the government are to be for the same annual rental. In this way, room is made for the Town to impose property taxes against the lessees. 
Ordinarily, where a landowner fails to pay property taxes, the ultimate weapon of the municipality is to force a tax sale of the property or, failing a successful sale, to assume ownership of the proprietary interest of the defaulting taxpayer. These same remedies are expressly open to the Town in the event of failure by a lessee to make tax payments. Of course, in that event, the Town will assume ownership of the foreclosed interest subject to the federal Crown's interest as lessor. In addition, however, Article 11 provides that Canada must seek to amend each existing lease to insert a clause whereby failure to pay taxes would be a ground for termination of the lease. All new leases must contain a like proviso. In the event that a lease is terminated for non-payment of taxes, subject to some limitations, the amount of the taxes owing are to attach to the land and to be assumed by any new lessee of the subject property.

Alberta and Canada each undertook in Article 8 to pay $\$ 1 \mathrm{M}$ to the Town, such sum to be used in the reconstruction of Banff Avenue, the Town's main thoroughfare. Both governments also agreed that the Town would be eligible to receive grants in lieu of tax payments in accordance with the respective governments' existing legislation ${ }^{68}$, and Alberta undertook to provide to the Town administrative and other services, along with funding, to the same extent as it does in the case of other Alberta towns. Policing is to be paid for by the Town to the degree that a comparable-sized town elsewhere in Alberta pays for its policing. The cost of additional policing required due to Banff being a prime centre for Park's visitors is to be borne by the Province. Finally, the provincial government also undertook to pay a "start-up" grant to the Town of $\$ 6.5 \mathrm{M}$, a matter agreed to between the Town and the Province outside of the context of the agreement. ${ }^{69}$

\section{DISSOLUTION OF THE TOWN}

Article 12 of the agreement contemplates that the Town may cease to exist in four circumstances:

- if the parties to the agreement mutually agree to dissolve the Town;

- if a court of competent jurisdiction adjudges that the Town has no legal existence;

- if a court of competent jurisdiction adjudges that the whole of the agreement is void or otherwise unenforceable; and

- if either party opts to terminate the agreement upon a court of competent jurisdiction adjudging part of the agreement to be illegal or unenforceable, or adjudges that the Agreement creates an agency relationship between Canada and the Town. ${ }^{70}$

Municipal Grants Act, R.S.C. 1985, c. M-13 and Crown Property Municipal Grants Act, R.S.A. 1980, c. C-38.

69. All payments required by Canada under the agreement are made subject to the Financial Administration Act, R.S.C. 1985, c. F-11. Sums committed by Alberta are similarly subject to the Financial Administration Act, R.S.A., 1980, c. F-9.

Article 13.9(3) expressly states that the parties agree that the Town is not an agent of Canada. This was inserted at the insistence of the Federal Treasury Board, which did not wish to expose itself to liabilities incurred by the Town. Of course, an undertaking between the parties that an agency relationship is not created is not determinative, and a court could very well find such an agency relationship exists despite the protestations -ontained in the agreement. 
To forestall the possibility of the creation of a regulatory hiatus, the parties also addressed what is to occur if the Town ceases to exist as a result of any one of the eventualities described. First, all real and personal assets transferred to the Town by Canada pursuant to the agreement (together with all replacements and additions thereto) automatically will revest in Canada free and clear of all encumbrances, and without any compensation being payable by Canada. Similarly, all real and personal assets (together with all replacements and additions thereto) acquired by the Town from the school board are to revert unencumbered to that board. ${ }^{71}$ Any outstanding debts of the Town, whether or not they operate to encumber the property described, are to be assumed by Alberta. Second, unless the parties otherwise agree, all the functions conferred upon the Town pursuant to the agreement that were previously exercised by Canada, without more, will revert to Canada. By the same token, all the municipal functions exercised by the school board prior to June $13,1988^{72}$ are to be exercised by the Board upon the Town's dissolution as though the Town had never existed as a corporate entity. Third, to prevent a legislative and administrative gap, all plans, by-laws and resolutions of the Town purporting to be in effect on the date the Town ceases to exist shall continue in effect as though they were federal regulations made under the National Parks Act. All powers exercisable by the Town (including its council, officers, boards, etc.) under such plans, by-laws, and resolutions may be exercised by the federal minister until such time as Canada makes alternative arrangements pursuant to the National Parks Act or any other federal legislation.

\section{E. MISCELLANEOUS PROVISIONS}

The concluding Article 13 of the agreement deals with a number of miscellaneous matters, most of which can be fairly described as typical "boiler-plate" clauses commonly found in business contracts. For example, it contains an undertaking for mutual indemnification against liabilities to third parties arising out of the breach of the agreement by one of the parties, an interpretation clause, a severability clause, a disclaimer clause, a non-waiver of breach clause and notice clauses. Three uncommon clauses contained in Article 13 warrant particular mention.

At the time the agreement was being drafted it was evident that some Parks Service employees would likely stand as candidates for Town council, there being no existing federal or provincial laws preventing such candidacy. However, the conflict of interest provisions contained in ss. 30 to 35 of the Municipal Government Act, which by the terms of the agreement apply in the Town, could pose serious difficulties for federal employees serving on the council. In particular, a council member must disclose any pecuniary

It is to be recalled that prior to incorporation the school board was in fact exercising certain municipal functions. These are taken over by the Town. Although not expressly dealt with in the agreement, it was understood that any assets of the board devoted to such functions as, for example, libraries, were to be taken over by the Town.

22. This date was chosen rather than the date of incorporation because, pursuant to transitional provisions contained in the agreement and orders made by the Minister of Municipal Affairs pursuant to the Parks Towns Act, the school board began to exercise certain municipal functions preparatory to incorporation on that date, which was the date of the plebiscite. 
interest in a matter before council, and then avoid participating in the debate and voting on the matter. Failure to comply could result in disqualification of the member from office and, of course, invalidate the action taken by council. A person is deemed by the Municipal Government Act to have a pecuniary interest in a matter if it is one that could "monetarily affect ... a government ... that employs the member of council", ${ }^{73}$ unless the member is an employee of the Government of Canada and the issue before council does not "directly affect"74 the department of which he or she is an employee. Much of a municipal council's business concerns making decisions that affect land values. Thus, since the Crown in right of Canada is the owner of practically all land in the Town, it is axiomatic that there would be great potential for the operation of the conflict of interest sections of the Municipal Government Act in the event that one or more council members is an employee of the federal government.

The parties to the agreement were of the view that it was not inappropriate for a federal government employee to serve on the Banff council, having regard to the large numbers of such employees residing in the townsite. Yet, without more, the conflict of interest deemed by the Alberta legislation would have the effect of both discouraging such employees from seeking office and, if a one did run and was elected, would necessitate the abstention of such a member on many important issues before the council. Accordingly, Article 13.13 was inserted providing that, subject to three exceptions, a member of council who is an employee of the federal government is not to be deemed for purposes of the Municipal Government Act to have a pecuniary interest in any matter before the council by reason only of the member being such an employee. The three exceptions are: where the matter concerns a proposed agreement between the Town and Canada, where the Town is seeking to acquire an interest in land from Canada or where the federal minister (or his delegate) appears on behalf of Canada before the council on a planning matter. Thus, Article 13.13 has the effect of modifying the application of the conflict of interest sections of the Municipal Government Act insofar as they apply to the Town.

It is noteworthy, however, that Article 13.13 does not necessarily entitle a council member who is an employee of Canada to participate in all but the excluded matters before Council that might affect the member's employer. The common law rules against bias on the part of a decision-maker will continue to apply, and breach of such rules by a council member could result in the invalidation of the decision made by council, although not in disqualification from holding office. However, because of Article 13.13, in the case of a federal employee, common law bias cannot be established merely by showing that the impugned council member voted on a matter affecting the financial interests of his or her employer.

The agreement requires that one member of the development appeal board must be a nominee of the federal minister. It is contemplated that the nominee will normally be a Parks Service employee. This also raises conflict of interest concerns since the 
development appeal board will always be engaged in making decisions affecting lands owned by the Crown in right of Canada. The agreement attempts to obviate such concerns by providing that a member of the development appeal board is not disqualified from participating in an appeal before the board on the sole ground that the member is an employee of Canada and the subject land is owned by the federal Crown.

At the time of its drafting, there was some uncertainty as to the agreement's precise legal status. At the very least, it can be said that creation of a governmental authority and delegation of power to it by an agreement is novel. Normally such action is taken in a statute or in a regulation made pursuant to a statute. If the entity is not properly established in accordance with the statute or regulation, as the case may be, or if it exercises powers contrary to the mandate conferred in its enabling statutory instruments, persons and other legally recognized entities with locus standi may seek redress through the well-established administrative law remedies that exist. The parties to the agreement intended that the document be regarded like any other statutory instrument that delegates governmental authority. Consequently, Article 13.15 provides that the agreement can be enforced against "the parties and the Town in the same manner and to the same extent as any statute, regulation or other public law". In other words, if for example the Town council exercises a power contrary to the agreement, the ordinary administrative law remedies and rules could be invoked by a third party to successfully challenge the council's actions. It is not altogether clear whether Article 13.15 will in fact accomplish the intended result.

\section{THE LEGAL STATUS OF THE TOWN}

To say the least, the foregoing discussion discloses that a government entity having jurisdiction to exercise legislative, administrative and quasi-judicial functions was created and endowed with powers in an unprecedented fashion. Normally, a government organ exercising delegated authority is clearly a creature of either federal or provincial making, and derives its powers from laws made by that government which created it, or through the process of inter-delegation. The Corporation of the Town of Banff is a hybrid - its legal existence is not attributable solely to one government or the other, nor are its functions. Hence, the mere existence of this novel creature raises a number of questions about its legal status.

The fundamental question is: Has the Canadian Constitution been adhered to in the form and manner in which the incorporation has been achieved? Section 15 of the Alberta Natural Resources Transfer Agreement contemplates that provincial laws apply in Banff except to the extent they are repugnant to any operative federal laws. Prior to the enactment of s. 8.1 of the National Parks Act in 1988, through the detailed provisions of the National Parks Act and regulations made thereunder, Parliament had effectively occupied much of the field normally allocated to provincially created municipal governments. However, by that section Parliament created a mechanism whereby federal laws pertaining to municipal matters could be rendered inoperative by executive action in the townsites of Banff and Jasper, thereby permitting provincial laws to apply. Parliament contemplated that the extent to which federal laws could be withdrawn and 
provincial laws allowed to apply would be determined by a federal-provincial agreement, which in turn was subject to the approval of the Governor General in Council.

Clearly, Parliament has the constitutional authority to choose whatever means it wishes to permit provincial laws to apply in national parks to the extent desired, including doing so through the mechanisms contemplated by s. 8.1. These mechanisms have been applied to Banff. In essence, subject to a number of conditions, Parliament has allowed Alberta laws to operate to create the Town and to endow it with powers. Section 8.1 is so broadly worded as to permit any and all provincial laws pertaining to municipal institutions to apply to the townsite. Since the greater includes the lesser, it was open to Canada to limit the extent to which provincial laws would apply, and to impose conditions upon their application. The agreement and the Minister's Instrument of Entrustment do precisely that: some provincial laws applying to Alberta towns will operate intact in Banff, some will operate with certain variations and others will not operate at all. This is in keeping with the spirit and intent of s. 15 of the Alberta Natural Resources Transfer Agreement.

Having provided for local government in Banff in the manner and to the extent set out in the agreement, it is open to Canada to change the agreement with the concurrence of the other signing party, the Province of Alberta, thereby altering either the form or substance, or both, of local government in Banff to the extent agreed upon. Conversely, the Alberta government could similarly change the agreement with the concurrence of Canada. The question remains: To what extent, if at all, could either Canada or Alberta unilaterally effect changes to the local government in Banff that has been created through the agreement?

As outlined earlier, the parties have expressly agreed that Canada may unilaterally change the land use planning and regulation provisions of the agreement under certain conditions. Also, either may elect to terminate the agreement in its entirety if any provision thereof is adjudged illegal or unenforceable by a court of law. That aside, it is highly unlikely that unilateral change can be effected by the executive branch of one government or the other, even though the agreement was entered into and approved at that level. Both Parliament, in s. 8.1 of the National Parks Act, and the Alberta Legislature, in s. 2 of the Parks Towns Act, have authorized their respective executives to enter into agreements pertaining to local government for Banff. By using the word "agreement", both legislative bodies must be taken to have intended that once it was executed, the agreement would be binding on the parties. Consequently, neither the Governor General in Council or the federal minister, acting for Canada, nor the Lieutenant Governor in Council or the Ministers of Municipal Affairs and Federal and Inter-governmental Affairs, acting for Alberta, may unilaterally alter the status of the Town of Banff, except as expressly provided for in the agreement.

However, Parliament itself is not bound by the agreement. The Constitution gives Parliament the exclusive jurisdiction to legislate in relation to national parks, except that provincial laws that do not conflict with federal laws may nevertheless apply. Parliament may not, through either a statute or an agreement, abdicate its constitutional mandate. If the incorporation agreement were binding on Parliament in the sense that it could never 
extricate itself from it, the effect would be to rewrite the Constitution in a manner not provided for in Part V of the Constitution Act, 1982. Moreover, Parliament cannot bind succeeding Parliaments by simply passing s. 8.1 of the National Parks Act. Therefore, it is open to Parliament to unilaterally withdraw from the arrangements set out in the agreement and to substitute whatever it deems fit in terms of governance of the Banff townsite. It would not, however, be open to Parliament to unilaterally amend the agreement per se by legislation since Parliament cannot foist on a provincial government that which the province is not obligated to do by the Constitution. There is no constitutional obligation on the Alberta Legislature to make laws in respect of Banff townsite or to provide for its administration.

Similarly, by statute, the Alberta Legislature could cause the Province to unilaterally withdraw from the arrangements set out in the incorporation agreement. The agreement was entered into by the Minister of Municipal Affairs on behalf of the Government of Alberta, and the Lieutenant Governor in Council incorporated the town only because the Alberta Legislature passed laws allowing those steps to be taken. As is the case with Parliament, one provincial legislature cannot fetter the legislative powers of succeeding legislatures. Consequently, by the expedient of repealing the statutory provisions that enabled Alberta's executive branch to incorporate the Town, the Legislature could unilaterally withdraw from the agreement. However, like Parliament, the Legislature could not make laws that would have the effect of changing the terms of the agreement without the concurrence of the federal government.

Another area of concern is whether the Town, in law, is a federal or provincial agency. Which it is determines whether legislation such as the Federal Court $\mathrm{Act}^{75}$ and the Official Languages $\mathrm{Act}^{76}$ apply to Banff.

Judicial review proceedings against a "federal board, commission or other tribunal" must be brought in the Federal Court to the exclusion of the provincial courts. ${ }^{77}$ A "federal board, commission or other tribunal" is defined as a body or person "exercising jurisdiction or powers conferred by or under an Act of Parliament, other than any such body constituted or established by or under a law of a province or any such person or persons appointed under or in accordance with the law of a province or under s. 96 of the Constitution Act, 1867." ${ }^{178}$ While the Corporation of the Town of Banff can perhaps be said to be exercising authority conferred under an Act of Parliament (namely s.8.1 of the National Parks Act), having regard to the terms of the incorporating agreement and the fact that it was created by provincial order in council pursuant to Alberta's Parks Towns Act, clearly the Town falls within the proviso contained in the Federal Court Act definition.

75. R.S.C. 1985 , c. F-7.

76. R.S.C. 1985, c. $0-3$

n. Federal Court Act, ss. 2, 18 and 28.

78. Ibid. s. 2. Note that even though a power is directly conferred on a provincially created agency by an Act of Parliament or a federal regulation, the exercise of the federally delegated power is not subject to review by the Federal Court. 
Similarly, the Town council is constituted under provincial legislation (the Municipal Government Act and the Local Authorities Election Act) and all of the Town's officers, committees and boards derive their existence from, and are appointed under, provincial legislation (e.g. the Municipal Government Act and the Planning Act).

Consequently, neither the Town nor its agencies are subject to the jurisdiction of the Federal Court. Instead, judicial proceedings against the Town and its agencies are governed by provincial laws to the same extent as are proceedings against any other town in Alberta. Moreover, this is expressly contemplated in the agreement since all of the Alberta law concerning legal proceedings against towns are referentially incorporated. ${ }^{79}$

Of course, any judicial review proceedings against actions taken by the federal minister (or any other federal agency) pursuant to the incorporating agreement will have to be taken in the Federal Court since the minister is clearly a federal tribunal within the meaning of the Federal Court Act.

The Official Languages Act requires that public instruments issued and all services performed by the "Institutions of the Parliament or Government of Canada" and "any judicial, quasi-judicial or administrative body or Crown Corporation established by or pursuant to an Act of Parliament" ${ }^{100}$ shall be in both the English and French languages. Again, since the Town of Banff and all its agencies derive their existence from Alberta law, the Official Languages Act likely does not apply. Admittedly, that Act does not contain an exception in its definitions like that in the Federal Court Act concerning bodies constituted or established under provincial law. Hence it could be argued that Banff and its entities are "established by or pursuant to an Act of Parliament" in that they are contemplated by s. 8.1 of the National Parks Act. However, such a view ignores the ordinary meaning of the words "established by or pursuant to", which suggest that there must be a direct link between the federal statute and the agency. Moreover, because of s. 15 of the Alberta Natural Resources Transfer Agreement, the Alberta law creating Banff and its agencies can be seen as operating ex proprio vigore rather than by operation of s. 8.1 of the National Parks Act. In effect, through the latter enactment and the Incorporation Agreement, Parliament has withdrawn in substantial part from the governing of Banff and has permitted provincial law to operate precisely as contemplated by the Natural Resources Transfer Agreement. Hence, the Town and its agencies do not fall within the purview of the Official Languages Act.

\section{CONCLUSION}

At the beginning of this paper the point was made that the Banff incorporation is a shining example of cooperative federalism. One must not, however, overstate the case. The Banff incorporation, with all that it entails in the way of substantial provincial jurisdiction, is not a bold example of Ottawa giving away power over a matter which the so as to exclude the jurisdiction of the Federal Court in respect of an agency that falls within the definition of a "federal board, commission or other tribunal." 
Constitution entrusts exclusively to Parliament. Rather, section 15 of the Alberta Natural Resources Transfer Agreement expressly contemplates a duality of jurisdiction within the national parks, subject to the paramountcy of federal laws. The incorporation agreement simply codifies the extent to which each jurisdiction, for the time being, will have lawmaking and executive powers. Moreover, the continuing control to be exerted by the federal government in Banff that has been described above 116 particularly in the areas of land use and the environment - negates any suggestion that Canada has demonstrated complete confidence in provincial lawmakers. Also sight should not be lost of the fact that in the final analysis Parliament can reassert complete control over Banff at any time it wishes. In addition, the cynic might suggest that there was a major Machiavellian element in so far as the federal government was concerned: the Banff townsite had achieved proportions that were beginning to outstrip Ottawa's capabilities. Hence, Ottawa has managed to extricate itself from most of the responsibilities for townsite administration without giving up control.

Nonetheless, it remains fair to say that local government for Banff is indeed the product of a somewhat uncharacteristic spirit of goodwill and cooperation between the two governments involved. One level of government normally seeks to enlarge its powers as against another, rather then the reverse. Hence, what transpired in Banff is quite novel. Admittedly, while in law Ottawa may not have given away the farm, to use a colloquialism, de facto, the Banff incorporation does represent a significant reordering of the constitutional division of powers. That reordering may, in reality, be unilaterally changed by the federal government, no matter what its political persuasion stripe, only at its electoral peril in Alberta. Hence, the political realities are such that, if anything, the future portends of even greater provincial jurisdiction in Banff, rather then less. 